\title{
Foreign Capital Flow in Niger: An Assessment of Impact Using System Equation Method
}

\author{
Amadou Maiga Ousseini' ${ }^{1}$, Xiaojuan $\mathrm{Hu}^{1}{ }^{1}$, Badamassi Aboubacar ${ }^{2}$ \\ ${ }^{1}$ School of Economics and Trade, Hunan University, Changsha, China \\ ${ }^{2}$ School of Economics and Management, China University of Geosciences, Wuhan, China \\ Email: aboubacarbadamassi@yahoo.fr, hdhxi@163.com, Ousseini22000@yahoo.fr
}

Received 5 June 2015; accepted 2 August 2015; published 5 August 2015

Copyright (C) 2015 by authors and Scientific Research Publishing Inc.

This work is licensed under the Creative Commons Attribution International License (CC BY). http://creativecommons.org/licenses/by/4.0/

c) (i) Open Access

\begin{abstract}
Capital inflow is an important factor for a country's economy. In this paper our main purpose is to investigate or to assess if the capital from abroad has a significant impact on economic growth in Niger. Our analysis takes data from 1980 to 2012 into consideration by using system equation method or the concept of cointegration and the vector error correction Model of GDP Growth Rate (GDPGR), Development Assistance (DASSIS), Foreign Direct Investment (FDI), Migrants' Remittance (MIGREMIT), Real Exchange Rate (REEXR) and Domestic Investment (DOMINV). We pay a particular attention on the impact of Development Assistance, Foreign Direct Investment, and Migrants' Remittance. The result of analysis shows an insignificant impact of Development Assistance (DASSIS), Foreign Direct Investment (FDI), on the growth in contrast with our expectation. Migrants' Remittance on his side has a significant relation on GDP performance.
\end{abstract}

\section{Keywords}

GDP Growth, Foreign Capital Flow, Time Series, System Equation, Niger

\section{Introduction}

Nowadays one of the focuses of international community is the development of poor countries. More attention has been focused on the importance of various sources of capital flows which can boost growth in developing countries.

The flow of capital from foreign countries is an important source of growth in developing countries despite the fact that economists do not consider much the analysis of combined effects of DA (Development Assistance), Migrant Remittance and FDI together on economic growth. The paper published by Nigel D. and Chris J. (2013)

How to cite this paper: Ousseini, A.M., Hu, X.J. and Aboubacar, B. (2015) Foreign Capital Flow in Niger: An Assessment of Impact Using System Equation Method. Theoretical Economics Letters, 5, 509-521.

http://dx.doi.org/10.4236/tel.2015.54060 
develops the subject giving importance of the interaction between institutions and others sources of growth. Overseas capital flows which include Official Development Assistance (ODA), Foreign Direct Investment (FDI), and Migrant Remittances have significantly grown and rise interest. Literature on the impact of Migrant Remittances is limited in contrast of literatures about the individual growth effect of FDI and Development Assistance.

The manner that these financial sources influences economic growth or development has been an interesting point of research for international economists. Nowadays there are so many literatures concerning the subject but there are also some controversial opinions about development assistance.

Statistical studies have produced widely differing assessments of the correlation between Development Assistance, FDI, Migrant Remittance and economic growth, and no firm consensus has emerged to suggest that foreign source of capital generally does boost growth in developing countries. Some studies find a positive correlation, but others find either no correlation or a negative correlation among Development Assistance, FDI and Migrant Remittance in developing countries, but each developing country has its own specificity. These specificities are the reasons for different results. Niger is a developing sub-Saharan African country. Like all developing economies, Development Assistance, FDI and Migrant Remittance are important sources for the promotion of the economic development and welfare of developing of that country. In this paper we are going to investigate the effect of foreign capitals on economic growth in Niger. Therefore, this research paper is going to undertake an analysis of the inflow impact of Development Assistance and Migrant Remittance.

Our article is organized as follows: The first part is the introduction. In the second section literature review, we provide a simple empirical growth literature for each source of foreign capital. The third part of the paper provides the methodology and analysis of foreign capital impact on growth in Niger. The fourth part provides conclusions and recommendations related to the results.

\section{Literary Review}

\subsection{Development Assistance}

Several economists had criticized and qualified Development Assistance as being an inappropriate way of helping developing economies or poor countries. Many literatures examine the impact of Development Assistance on economic growth in developing countries and there are so many debates on the subject. Some arguments are considering as sensational and controversy but some literature also found statistical evidence of Development Assistance on growth.

Riddell [1], see Development Assistance under solidarity or humanitarian imperative and a response of poverty and inequality in developing countries. Many supporters think that Development Assistance can be a source of peaceful and safe world and promote human right (See Sen [2]). Veiderpass et al. [3], found no clear pattern when it comes to the relation between aid and efficiency development, however, their findings are inconclusive. Sanjay G. Reddy and Camelia Minoiu [4], analyzed the growth impact of official Development Assistance to developing countries. They found that the effect of developmental aid or Development Assistance is significant, large, and withstands a battery of robustness checks including alternative proxies for developmental aid, specifications and treatments of outliers. But they disentangle the effects of two components of aid: a developmental, growth enhancing component, and a geopolitical, possibly growth depressing component.

Recent previous articles like Easterly et al. [5], Burnside and Dollar [6], find that on its own aid has no effect on growth even if it is interacted with monetary and fiscal policy environment there is a conditional effect. Some articles show that countries that are highly corrupted are receiving more aid and the deterioration of governance in Africa is associated by more aid. These arguments are steamed respectively by Alesina and Weder [7], and Brautigam and Knack [8]. According to Moyo [9], in "dead aid" Development Assistance or Aid is not working and has not strongly promoted economic growth in Africa. She upholds her saying with many and strong arguments but she is accused of being sentimental and controversy. Baeur [10], consider assistance as wealth distribute by poor people in rich countries directly to rich people in poor countries. Driffield and Jones [11] found that all sources of foreign capital have a positive and significant impact on growth when institutions are taken into account.

\subsection{Migrant's Remittance}

From a macroeconomic perspective, remittances can boost aggregate demand and thereby GDP as well as spur 
economic growth. However, some research indicates that remittances may also have adverse macroeconomic impacts by increasing income inequality and reducing labor supply among recipients (See, Pia et al. [12]).

Literature investigations about remittances impact on economic produced diverse conclusion. On the positive side, remittances contribute to the alleviation of poverty and, in some instances, provide capital to fund households' investments and savings. Many countries have known macro-economic growth driven by remittance and mostly by increasing national disposable income.

Remittance is considered as playing a positive role in enhancing individual household status, community and country by functionalist Neo-liberal (See, Skeldon [13]). A study by Lucas [14] show the case of several countries like morocco, Pakistan and India where remittance may play considerable role to enhance investment. The econometric results by Baldé [15] show that remittances do not have direct positive impact on economic growth in SSA. However, remittances may have indirect positive impact on growth through several channels such as investment or education.

According to Roberts and Banaian [16], empirical evidence suggests on Armenia, that the propensity to save out of remittance income is high (almost $40 \%$ ) and remarkably consistent across studies. Analysis conducted by Leon-Ledesma and Piracha [17] for eleven transition economies of Eastern Europe during 1990-1999 show support for positive impact on productivity and employment directly and indirectly via their effect on investment.

Faini [18] [19] found a positive impact of remittances on growth and interpreted the positive coefficient on the policy stance to indicate that in order for the full impact of remittances to be realized, which allow households to accumulate productive assets. He also found a positive impact of remittance on growth and that good political environment contributes positively to this impact. Catrinescu et al. (2008) taking in consideration the institutional variables found a positive impact although fragile. Ratha [20] finds that during 1996-2000, remittance receipts averaged 0.5 percent of GDP in countries with a higher-than-median level of corruption compared to 1.9 percent in countries with lower-than-median corruption, giving an indication that corruption has an effect on the level of income generated from remittances

Bettin and Zazzaro [21] depending to the econometric specification adopted or variables of financial development taken into account, they found positive and significant results. Ledesma et al. [22] find that remittances exert a weakly positive impact on long-term macroeconomic growth. Authors like Chami et al [23], Azam and Gubert [24] argue about the negative effect of migrant's remittance.

\subsection{FDI}

FDI is an import financial source for economic growth, especially for developing countries like Sub-Saharan Africa. One of the objectives of this paper is to analyze FDI impact on economic growth in Niger. Nowadays, it is showed that the vast majority of the fast growing economies relied heavily on FDI to jump-start and sustain their rapid economic transformation (See, Ajayi et al. [25]). The importance to FDI to the economic growth has led some of sub-saharan African countries to put in place various measures-apart from improving their investment environment — that they hope will attract foreign direct investment to their economies (Ajayi et al. [25]).

The bulk of the financing will have to come from abroad mainly from official sources, from foreign direct investment With the exception of a few countries (See, Sun 2006) According to Ajayi et al. [25] African continent did not benefit from the FDI boom that began in the mid-1980s. In the period 1991-96, while the world average FDI inflow was $\$ 401.7$ billion, Africa’s average for that period was a mere $\$ 7.1$ billion, a world share of 1.8 percent. Other regions of the world received more than Africa.

Among the effect of FDI is the transfer of technology may have substantial spillover effects in the entire economy (See, Carkovic and Levine 2004). the transfer of technology through FDI in developing countries is especially important because most developing countries lack the necessary infrastructure in terms of an educated population, liberalized markets, economic and social stability that are needed for innovation to promote growth (Calvo and Sanchez-Robles [26]).

Some authors like Akinlo [27], Ayanwale [28], Hermes and Lensink [29], in contrat of those who found a positive correlation between FDI and economic growth found a non-significant or negative effect. It is important to notice that the effect of FDI is more important in a country with important domestic investment and/or good investment environment. Keshava (2008), has shown that domestic investment is more effective than FDI in promoting growth as it is showed in the case of china and others Asian countries. The objective of this paper is 
also to analyze the impact of FDI on economic performance in Niger with a combination of other variables that can be important to economic growth and to drive also FDI inflows in the county using econometric methods.

In sum, literature about whether foreign capital (Development Assistance, FDI, migrant remittance) has significant impact on growth in developing countries has produced several, different and in some extends controversial results. Many authors found that Development Assistance have insignificant or in some case negative impact on growth as sustained by authors like Moyo Dambissa in "dead aid". Easterly et al. [5], Burnside and Dollar [6] found no effect of Development Assistance on growth although some literature sustains idea in favor of Development Assistance. FDI significance on growth in developing countries has been and continues to be an important subject in economic literature. FDI is found in most case enhancing growth although contrast results were found in some case of extractive FDI. Remittance is considered as playing a positive role in enhancing individual household status, community and country by functionalist neo-liberal. Literature about transition economies of Eastern Europe show positive impact on productivity and employment effect on investment. Some authors found that remittances contribute to the alleviation of poverty and, in some instances, provide capital to fund households' investments and savings in developing countries. It is found to drive macro-economic growth mostly by increasing national disposable income.

\section{Analysis Framework}

\subsection{Data Definition}

We begin by specifying a production function in which includes time series data of macroeconomic variables of foreign capital flow in the country defined by the composition of Development Assistance (DASSIS) received from outside or financial institutions like IMF or bring by World Bank, European Union and other, the private capital flow which is defined by the Foreign Direct Investment (FDI) inward in the country from all over the world and the Migrants Remittance (MIGREMIT). These variables are used because they represent the main explanatory variables and our study depicts their effects on GDP growth (GDPGR). FDI is used as an important factor of capital as the country enclosed in its basement significant mineral resources that attracts Foreign Direct Investments. Exchange rate variable is used because it is a critical variable in the determination of the capital account; the domestic investment is used as it represents an important component of GDP which provides an indicator of the productive capacity of the economy in future.

\subsection{Modeling Approach}

The analysis uses a model based on the seven (6) variables that previously has been mentioned in the data definition. That model is built in order to assess the relationship among them. So the assumption is that GDPGR is a function of DASSIS, FDI, MIGREMIT, DOMINV and REEXR.

The model is expressed as follows:

$$
\text { GDPGR }_{t}=F\left[\text { DASSIS }_{t}, \text { FDI }_{t}, \text { MIGREMIT }_{t}, \text { DOMINV }_{t}, \text { REEXR }_{t}\right] \text {, where } t \text { denotes the time. }
$$

Citing B. Aboubacar, D. Xu, A.M. Ousseini (2014) [30], to estimate properly the parameters and facilitate the interpretation, a logarithmic transformation is made to the variables which do not contain negative and/or zero values. We precisely transform DASSIS, MIGREMIT, DOMINV and REEXR. We can specify the final model as:

$$
\Delta \mathrm{GDPGR}=\alpha+\beta_{1} \Delta \ln \mathrm{DASSIS}+\beta_{2} \Delta \mathrm{FDI}+\beta_{3} \Delta \ln \mathrm{MIGREMIT}+\beta_{4} \Delta \ln \mathrm{DOMINV}+\beta_{5} \Delta \ln \mathrm{REEXR}+\varepsilon
$$

Before working with our multivariate model data should be test for unit root. According to Hendry and Juselius (2000) [31], time series data must of the time represent unit root behavior. Such data cannot be used to investigate relationships between the variables because of spurious regression problem, so using OLS for estimate time series become invalid. However, data showing such properties can be made stationary by first differencing. According to Granger and Swanson [32], if a series is such that its first difference is stationary (and has positive spectrum at zero frequency) then the series has an exact (or pure) unit root.

We start our unit root test by the autoregressive process of degree one Equation (1) below, denoted as AR (1) process.

$$
\Delta y_{t}=\Delta y_{t-2}+\varepsilon_{t}
$$


Starting from the equation above, we can show that subtracting on both sides will result in a stationary process even though is non-stationary, i.e.

$$
y_{t}-y_{t-1}=\Delta y_{t}+\varepsilon_{t}
$$

Such differencing can be extended to twice-integrated series or more i.e. I (2), in which case it must be differenced twice to deliver a stationary process etc.

The Augmented Dickey-Fuller test (ADF) can be applied to check whether the series are stationary or it is not; if time series variable, $Y_{t}$, is stationary then:

1. The expected value of $Y_{t}, E\left(Y_{t}\right)$ is the same for all values of $t$;

2. The variance of $Y_{t}, \operatorname{Var}\left(Y_{t}\right)$ is finite and the same for all values of $t$;

3. $\operatorname{Cov}\left(Y_{t}, Y_{t-s}\right)$ depends only on $\mathrm{s}$, but not on $t$.

then if the time series variable is not stationary:

1. $E\left(u_{t}\right)=0$;

2. $\operatorname{Var}\left(u_{t}\right)=\sigma_{u}^{2}$;

3. $\operatorname{Cov}\left(u_{t}, u_{t-s}\right)=0($ for $s \neq 0)$.

\subsection{Unit Root test}

Dickey and Fuller (1979) had developed the test whether variable has a unit root. The null hypothesis for this test is that the variable that is in use for analysis contains a unit root.

For the unit root test, the AR (1) model as the Equation (1) is reproduced adding a constant term $\alpha$, time trend and a coefficient that are so significant in the development for the test statistic.

$$
\Delta y_{t}=\alpha+\rho y_{t-1}+\partial t+\varepsilon_{t}
$$

An extension of Equation (4) is done to remove possibilities of serial correlation in the lagged variables by taking $p$ lagged differences and fitting a model as shown in Equation 5

$$
\Delta y_{t}=\alpha+\beta y_{t-1}+\partial t+\varphi_{1} \Delta y_{t-1}+\varphi_{2} \Delta y_{t-2}+\varphi_{3} \Delta y_{t-3}+\cdots+\varphi_{k} \Delta y_{t-k}+u_{t}
$$

For the unit test, four possibilities are available to us depending on constraints placed on the constant and time trend and that are summarized in the Table 1.

\section{Unit Root Test Result}

For the Dickey-Fuller test, if the test statistics is smaller (larger) than the critical values we do not reject (reject) the null hypothesis of unit root in the data.

The unit root test statistics starts from the Augmented Dickey-Fuller expression (Equation (6)) below.

$$
\Delta y_{t}=\alpha+\beta y_{t-1}+\partial t+\varphi_{1} \Delta y_{t-1}+\varphi_{2} \Delta y_{t-2}+\cdots+\varphi_{k} \Delta y_{t-k}+\varepsilon
$$

where $k$ is the number of lags specified in the lags ( ) option. The non-constant option removes the constant term $\alpha$ from this regression, and the trend option includes the time trend $\partial t$, which by default is not included. Testing $\beta=0$ is equivalent to testing $\rho=1$, or, equivalently, that $y_{t}$ follows a unit root process (Stata Press Publication, 2013).

There are many unit root tests but here we used the Augmented Dickey-Fuller test. It performs the test that a variable follows a unit-root process. The null hypothesis is that the variable contains a unit root. So, if the

Table 1. Augmented Dickey-Fuller unit root test constrains on constant and time trend possibilities.

\begin{tabular}{cccc}
\hline Possibilities & Process under $\mathrm{H}_{0}$ & Regression restrictions \\
\hline 1 & Random walk without drift & $\boldsymbol{\alpha}=\mathbf{0} \boldsymbol{0}=\mathbf{0}$ & dfuller option \\
2 & Random walk without drift & $\boldsymbol{0}=\mathbf{0}$ & noconstant \\
3 & Random walk with drift & none & drift \\
4 & Random walk with or without drift & trend
\end{tabular}


P-value of the coefficient of a variable is less than $5 \%$ level of significance (P-value $<0.05$ ), we reject the null hypothesis and conclude that the variable is stationary otherwise we accept it. We can say also that if the absolute value of the test statistic is greater than the $5 \%$ critical value, we can reject the null hypothesis of unit root otherwise we fail to reject the null hypothesis.

The first test of unit root shows that the variables are not stationary but after differencing the Augmented Dickey-Fuller test Table 2 below shows that all variables are stationary.

The results reported in Table 2 above show that the variables follow a stationary process.

The results in the Table 3 below show that the AIC, HQIC, and the LR test all chose three lags. This means our multivariate model will be explained by three lags because three criteria are suggesting choosing three lags against two criteria. Once we have determined the number of lags, the next step is to test for co-integration among our variables.

\subsection{Cointegration Test}

In order to verify the existence of long-run relationship between the variables by determining the presence and the number of co-integrating equations; The Johansen's trace statistics method for determining $r$, the number of co-integrating equations used here can be interpreted as being an estimator $\hat{r}$ of the true number of co-integrating equations $r$. The method starts testing at $r=0$ and accepts $\hat{r}$ the first value of $r$ for which the trace statistic fails to reject the null hypothesis (if the trace statistic is less than its $5 \%$ critical value) that there are no more than $r$ cointegrating relations. Unlike the Engel and Granger test, the Johansen-Juselius approach provides not

\section{Table 2. Augmented Dickey-Fuller Test’s Results after differencing.}

\begin{tabular}{cccc}
\hline variables ADF Test Statistic & $\begin{array}{c}\text { 5\% Critical value } \\
\text { of ADF Test statistic }\end{array}$ & $\begin{array}{c}\text { P-values } \\
\text { (5\% level of significance) }\end{array}$ & Order of Remarks integration \\
\hline Lndassis -6.815 & -2.983 & $0.0000^{*}$ & $\mathrm{I}(1) 1^{\text {st }}$ order Difference stationary \\
Fdi -5.841 & -2.983 & $0.0000^{*}$ & $\mathrm{I}(1) 1^{\text {st }}$ order Difference stationary \\
Inreexr -5.864 & -2.983 & $0.0000^{*}$ & $\mathrm{I}(1) 1^{\text {st }}$ order Difference stationary \\
Lndominv -6.249 & -2.983 & $0.0000^{*}$ & $\mathrm{I}(1) 1^{\text {st }}$ order Difference stationary \\
Lnmigremit -5.152 & -2.983 & $0.0000^{*}$ & $\mathrm{I}(1) 1^{\text {st }}$ order Difference stationary \\
\hline
\end{tabular}

* Stationary at 5\% level of significance.

Table 3. Lag Selection-order criteria before Cointegration.

\begin{tabular}{|c|c|c|c|c|c|c|c|c|}
\hline lag & LL & LR & df & $\mathrm{p}$ & FPE & AIC & HQIC & SBIC \\
\hline 0 & -169.705 & - & - & - & 0.011371 & 12.5504 & 12.6376 & $12.8358^{*}$ \\
\hline 1 & -140.239 & 58.932 & 36 & 0.009 & 0.019347 & 13.0171 & 13.628 & 15.0154 \\
\hline 2 & -107.153 & 66.172 & 36 & 0.002 & 0.035425 & 13.2252 & 14.3597 & 16.9364 \\
\hline 3 & -15.8226 & $182.66^{*}$ & 36 & 0.000 & 0.00253 & $9.27304^{*}$ & $10.9312^{*}$ & 14.697 \\
\hline 4 & - & - & 36 & - & $-2.0 \mathrm{e}-50 *$ & - & - & - \\
\hline ‘*, & \multicolumn{8}{|c|}{ An appears next to the LR statistic indicating the optimal lag } \\
\hline LL & \multicolumn{8}{|c|}{ log likelihood } \\
\hline LR & \multicolumn{8}{|c|}{ likelihood ratio(sequential modified LR test statistic (each test at 5\% level)) } \\
\hline FPE & \multicolumn{8}{|c|}{ final prediction error } \\
\hline AIC & \multicolumn{8}{|c|}{ Akaike's information criterion } \\
\hline HQIC & \multicolumn{8}{|c|}{ Hannan and Quinn information criterion } \\
\hline SBIC & \multicolumn{8}{|c|}{ Schwarz's Bayesian information criterion } \\
\hline
\end{tabular}


only a test for co-integration but also reveals the number of co-integration relationships; thus, justifying our choice of the Johansen-Juselius co-integration test

$$
\Delta y_{t}=\alpha\left(\beta y_{t-p}+\mu+\rho t\right)+\sum_{i=1}^{p-1} \Gamma_{t} \Delta_{t-1}+y+\tau t+\varepsilon_{t}
$$

In Table 4 below, the trace statistics at $r=0, r=1, r=2, r=3$ with 190.5269, 127.0069, 65.2485, respectively exceeds their critical value of $94.15,68.52,47.21$, respectively, so the null hypothesis is reject of cointegrating equations. The trace statistics at $r=3$ of 21.3294 is less than the critical value of 29.68; therefore we cannot reject the null hypothesis that there is cointegration relationship between GDP growth and DASSIS, FDI, MIGREMIT, DOMINV, REEXR. The variables are cointegrated or they have long run association ship it also means that GDP growth and Development Assistance, FDI, Migrants Remittance, Domestic Investment, exchange rate is moving together in the long run.

\subsection{Testing for Cointegration and VECM Result}

The cointegration table indicates that all the variables have long run relationship.

The output Table 5 confirms also that the number of rank to be 3 in the model at both $5 \%$ and the variables are moving together in the long run. In that case the VECM model can be used in the analysis. After determining that there is indeed a long run co-integration relationship between GDP growth and DASSIS, FDI, MIGREMIT, DOMINV, REEXR, the next step of our analysis is to collect the VECM estimates.

The test of co-integration tell us that our variables have more than one co-integrated relationship so as variables are co-integrated, VECM model with one co-integration relation only in the box to see the relation of GDP Growth and the independent variables.

The head of our VECM table provides information about the sample, the model fit, and the identification of the parameters in the co-integrating equation (Figure 1). The table's main estimation contains the estimates of the short-run parameters, along with their standard errors and confidence intervals. The second table reports the estimates of the parameters in the co-integrating equation, along with their standard errors and confidence intervals.

\begin{tabular}{|c|c|c|c|c|c|}
\hline Maximum rank & Parms & LL & eigenvalue & trace statistic & $5 \%$ criticalvalue \\
\hline 0 & 78 & -142.13802 & - & 190.5269 & 94.15 \\
\hline 1 & 89 & -110.37804 & 0.88812 & 127.0069 & 68.52 \\
\hline 2 & 98 & -79.49884 & 0.88112 & 65.2485 & 47.21 \\
\hline 3 & 105 & -57.539275 & 0.78007 & $21.3294^{*}$ & 29.68 \\
\hline 4 & 110 & -53.589012 & 0.23847 & 13.4289 & 15.41 \\
\hline 5 & 113 & -50.07781 & 0.21506 & 6.4065 & 3.76 \\
\hline 6 & 114 & -46.874574 & 0.19821 & - & - \\
\hline
\end{tabular}

Table 5. Johansen tests for co-integration (maximum eigenvalue).

\begin{tabular}{|c|c|c|c|c|c|}
\hline Maximum rank & parms & LL & eigenvalue & max statistic & $5 \%$ criticalvalue \\
\hline 0 & 78 & -142.13802 & . & 63.5200 & 39.37 \\
\hline 1 & 89 & -110.37804 & 0.88812 & 61.7584 & 33.46 \\
\hline 2 & 98 & -79.49884 & 0.88112 & 43.9191 & 27.07 \\
\hline 3 & 105 & -57.539275 & 0.78007 & 7.9005 & 20.97 \\
\hline 4 & 110 & -53.589012 & 0.23847 & 7.0224 & 14.07 \\
\hline 5 & 113 & -50.07781 & 0.21506 & 6.4065 & 3.76 \\
\hline 6 & 114 & -46.874574 & 0.19821 & - & - \\
\hline
\end{tabular}




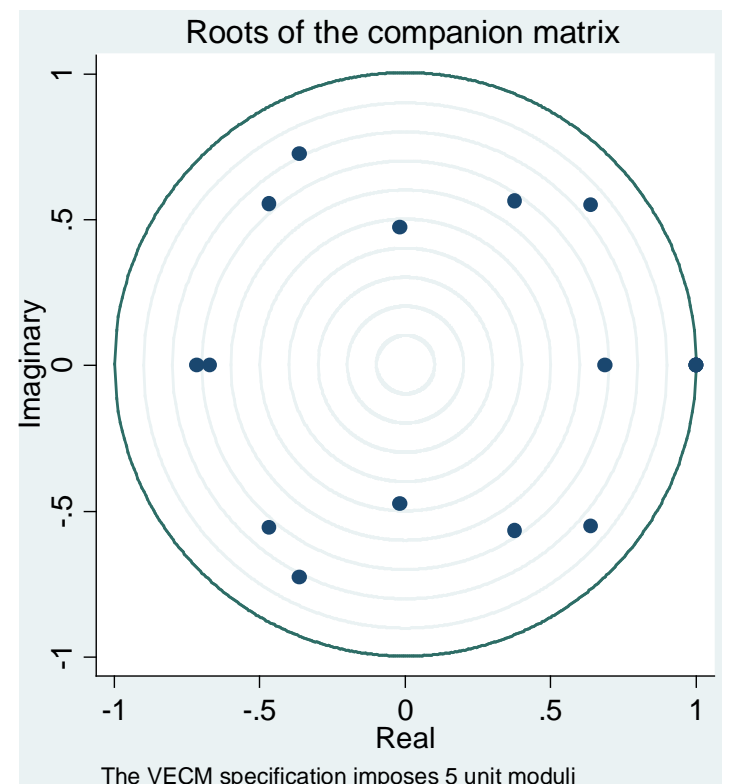

Figure 1. Stability test for the co-integration relationship.

The short run estimates concerning our analysis are read from the first part of the VECM resume in the Table 6. The coefficients on $\mathbf{L}$._ce1 make up the long run disequilibrium adjustment matrix $\boldsymbol{\alpha}$ for our model. The short run coefficients contained in $\boldsymbol{\Gamma}$ are collected from the row coefficients of the lagged differences (LD) and the constant matrix is read from the row of constants (_cons) in the first part of the table.

The second part of the VECM Table represents the $\boldsymbol{\beta}$ parameters of the co-integrating vector.

The adjustment coefficient $\alpha$ :

$$
\alpha=(-1.006709,0.0108533,23.27922,-0.0428634,-0.012456,-0.010595)
$$

The error correction term or speed of adjustment toward long run equilibrium is $\mathbf{- 1 . 0 0 6}$, that coefficient is negative and his P-value is not significant that mean that there is insignificant long run causality running form Indassis, fdi, Inreexr, Indominv, and Inmigremit to GDPGR.

Looking at the short run coefficient of Development Assistance (Indassis), we can see that the P-value of the coefficients Development Assistance, FDI, Migrant Remittance (Inmigremit) that are our target variables are not significant considering their P-value at 5\% level of significance to explain the GDP growth (GDPGR). The adjustment parameters generally are small, implying a slow correction to equilibrium. The adjustment parameter on Migrant Remittance is small and significant meaning that it does adjust contemporaneously to changes in GDPGR as it is expected. The adjustment parameter on the Development Assistance (Indassis) is small and no significant, meaning that it does not adjust contemporaneously to changes in GDPGR as we expected but The adjustment parameters on FDI is not small as we expected.

\subsection{Short Run Causality (Table 7)}

At this step of the analysis we test whether the target variables have an influence on the GDP growth (GDPGR). The main expectation is to find that Development Assistance, FDI, and Migrant Remittance influence (cause) growth in Niger considering the time 1980 to 2012 in the short run. So we test whether the target independent variables cause the dependent variable. The test will consist of whether Development Assistance, FDI, Migrant Remittance, Domestic Investment and Real Exchange Rate cause the growth of GDP or not. The null hypothesis is that there is no short-run causality between the target independent variables and the dependent variables. Granger causality method is used to check if the null hypothesis is rejected or not.

For Development Assisance, FDI and Migrant Remittence, the test reveal that we can reject the null hypothesis at $5 \%$ level of significance, there is no short run causality running from Development Assistance, FDI and Migrent Remittence to GDP Growth (GDPGR) as for the other independent variables. we can say that in short run Development Assistance, FDI and Migrant Remittance do not influence or cause GDP Growth (GDPGR). 
Table 6. Short run parameters.

\begin{tabular}{|c|c|c|c|c|c|c|c|c|}
\hline & & & Coef. & Std. Err. & $\mathrm{z}$ & $\mathrm{P}>|\mathrm{z}|$ & \multicolumn{2}{|c|}{ [95\% Conf. Interval] } \\
\hline \multirow{14}{*}{$\Gamma$} & D_gdpgr & $\begin{array}{c}\text { ce1 } \\
\text { Lag } 1 .\end{array}$ & -1.006709 & 0.9170136 & -1.10 & 0.272 & -2.804023 & 0.7906046 \\
\hline & \multirow{2}{*}{ gdpgr } & LD. & 0.2575891 & 0.990607 & 0.26 & 0.795 & -1.683965 & 2.199143 \\
\hline & & L2D. & -0.0345607 & 0.4379967 & -0.08 & 0.937 & -0.8930185 & 0.8238971 \\
\hline & \multirow{2}{*}{ Indassis } & LD. & 28.31821 & 18.87499 & 1.50 & 0.134 & -8.676079 & 65.31251 \\
\hline & & L2D. & 10.42072 & 12.80341 & 0.81 & 0.416 & -14.6735 & 35.51495 \\
\hline & \multirow{2}{*}{ fdi } & LD. & 0.0237729 & 0.0226155 & 1.05 & 0.293 & -0.0205526 & 0.0680984 \\
\hline & & L2D. & -0.0169905 & 0.0219394 & -0.77 & 0.439 & -0.0599909 & 0.0260099 \\
\hline & \multirow{2}{*}{ Inmigremit } & LD. & -0.7018196 & 13.30524 & -0.05 & 0.958 & -26.77961 & 25.37597 \\
\hline & & L2D. & 23.54069 & 18.12892 & 1.30 & 0.194 & -11.99135 & 59.07273 \\
\hline & \multirow{2}{*}{ Indominv } & LD. & -24.94447 & 21.95616 & -1.14 & 0.256 & -67.97775 & 18.08881 \\
\hline & & L2D. & 0.2448933 & 10.0216 & 0.02 & 0.981 & -19.39707 & 19.88686 \\
\hline & \multirow{2}{*}{ Inreexr } & LD. & 16.56415 & 36.25676 & 0.46 & 0.648 & -54.49779 & 87.62609 \\
\hline & & L2D. & -97.13586 & 51.76086 & -1.88 & 0.061 & -198.5853 & 4.313567 \\
\hline & \multicolumn{2}{|c|}{ cons } & 0.1954882 & 1.929199 & 0.10 & 0.919 & -3.585673 & 3.976649 \\
\hline
\end{tabular}

Table 7. Short run causality test.

\begin{tabular}{cccc}
\hline & Causality & Chi square (chi2) (2) & Pro > chi2 \\
\hline Development Assistance cause GPDGR & no & 2.54 & 0.2815 \\
Migrant remittance cause GPDGR & no & 1.79 & 0.4093 \\
FDI cause GPDGR & no & 1.11 & 0.5752 \\
Real exchange rate cause GPDGR & no & 3.69 & 0.1582 \\
Domestic investment cause GPDGR & no & 27.631 .48 & 0.4772 \\
\hline
\end{tabular}

The second part of our estimate VECM table represents the co-integrating vector that is the interest matrix $\boldsymbol{\beta}$ parameters:

$$
\boldsymbol{\beta}=(1,2.468616,0.0008336,15.75375,-20.0048,25.71381)
$$

The long run relationship between GDP Growth (GDPGR) and Development Assistance (Indassis), Foreign Direct Investment (FDI), Migrant Remittance (MIGREMIT), Domestic Investment (DOMINV) and Real Exchange Rate (REEXR) is summarized in the equation below.

The VECM table shows that coefficient Development Assistance (Indassis), FDI are not significant by their P-value of $0.145,0.628$ at $5 \%$ level of significance but the coefficient of Migrant Remittance (Inmigremit), Domestic Investment (Indominv), and Exchange Rate (Inreexr) with P-value of 0.000 for both variables.

$$
\begin{aligned}
\text { GDPGR }= & 2.468616 \text { lndassis }-0.0008336 f d i+15.75375 \text { lnmigremit } \\
& -20.0048 \text { lndominv }+25.71381 \text { lnreexr }+88.45812
\end{aligned}
$$

The long run relationship between the GDP Growth (GDPGR) and the target variables tells us that Development Assistance and FDI have insignificant relation with growth, but different observation is done for Migrant Remittance.

The results (Table 8) show that 12 eigen values are strictly less than one, thus confirming stability of multivariate model. 
Table 8. Stability test for the co-integration relationship (Eigen value stability condition).

\begin{tabular}{|c|c|c|c|}
\hline \multicolumn{3}{|c|}{ Eigen value } & modulus \\
\hline \multicolumn{3}{|c|}{1} & 1 \\
\hline \multicolumn{3}{|c|}{1} & 1 \\
\hline \multicolumn{3}{|c|}{1} & 1 \\
\hline \multicolumn{3}{|c|}{1} & 1 \\
\hline \multicolumn{3}{|c|}{1} & 1 \\
\hline-6372693 & + & $-2207671 i$ & -842292 \\
\hline-6372693 & - & $-2207671 i$ & -842292 \\
\hline-3636057 & + & $-726556 i$ & -812461 \\
\hline-3636057 & - & $-726556 i$ & -812461 \\
\hline-4662039 & + & $-5555478 i$ & -725244 \\
\hline-4662039 & - & $5555478 i$ & -725244 \\
\hline-7177932 & & & -717793 \\
\hline-6873123 & & & -687312 \\
\hline-3776197 & + & $-564292 i$ & -678986 \\
\hline-3776197 & - & $-564292 i$ & -678986 \\
\hline-6720116 & & & -672012 \\
\hline-01946636 & + & $-4734391 i$ & -473839 \\
\hline-01946636 & - & $-4734391 i$ & -473839 \\
\hline & The VEC & poses 5 unit & \\
\hline
\end{tabular}

In this, at the $5 \%$ level, we cannot reject the null hypothesis that there is no autocorrelation in the residuals for any of the orders tested. The Lagrange multiplier test of the model shows that the null hypothesis of no autocorrelation is accepted which is a satisfaction for the model. In other words, the model does not suffer of autocorrelation. We can say also that this test finds no evidence of model misspecification.

\subsection{Test for Autocorrelation (Lagrange Multiplier Test)}

In co-integration analysis (last part of Table 9), the data used has been corrected for unit root processes and therefore autocorrelation. This means that even though our independent variables which are expected to have strong correlation to independent variable, the removal of unit root and also autocorrelation in long run co-integration analysis removes this problem. A residual normality test of jarque-Bera (Table 10) of whether the residual are normally distributed show that the residuals of the model are normally distributed for the variables and for the whole model as expected.

Our finding is that Development Assistance do not work in the short run to promote subsequent economic growth that raises a number of important questions of why is Official Development Assistance from abroad does not work to promote growth in Niger. The same conclusion is observed for FDI and Migrant Remittance. In the other hand, the long run relationship between the GDP Growth (GDPGR) and the target variables tells us that Development Assistance and FDI have insignificant relation with growth, but different observation is done for Migrant Remittance. By the end we can say that only Migrant Remittance satisfy our expectation in the long run. Different test to check the goodness of our model show the model is good. 
Table 9. Lagrange-multiplier test.

\begin{tabular}{cccc}
\hline Lag & chi2 & df & Prob $>$ chi2 \\
\hline 1 & 32.8974 & 36 & 0.61694 \\
2 & 53.2787 & 36 & 0.03178 \\
3 & 42.6757 & 36 & 0.20602 \\
& H0: no autocorrelation at lag order & \\
\hline
\end{tabular}

Table 10. Jarque-Bera test of residual distribution.

\begin{tabular}{cccc}
\hline Equation & chi2 & df & Prob > chi 2 \\
\hline D_gdpgr & 1.867 & 2 & 0.39323 \\
D_lndassis & 2.731 & 2 & 0.25527 \\
D_fdi & 3.668 & 2 & 0.16004 \\
D_lnmigremit & 0.558 & 2 & 0.75638 \\
D_lndominv & 1.469 & 2 & 0.47978 \\
D_lnreexr & 3.168 & 2 & 0.20516 \\
ALL & 13.457 & 12 & 0.33669 \\
\hline
\end{tabular}

\section{Conclusion and Recommendation}

The main expectation of the analysis is to find that the target variables have a significant and positive impact on economic growth. The result of the analysis shows that development and FDI do not satisfy the expectation in the case of the republic of Niger. None of the target (explanatory) variables influences economic growth in short-run. Among the reasons why Development Assistance does not impact significantly on growth can be the misappropriation of the fund to the real objectives which are the development and welfare. FDI on its side also is not significant. Considering the important mineral resources of the country, it is showed by some literature that extractive FDI may not be growth inducing as much as manufacturing FDI as we know that Niger's FDI is mainly extractive.

The result shows that Migrant Remittance has a significant impact on GDP growth in Niger in long-term. The result is in support of so many researches that show the positive impact of remittance on growth. Niger is not an exception from previous researches.

\section{Recommendation}

In consideration of the findings, the study recommends the following policies:

Capitals received as Development Assistance should be used to build the infrastructure which is crucial for boost agricultural and industrial development of the country. It is important for government to ensure that corruption and flight of capital is limited as possible by setting in place audit and control systems which will allow the effectiveness of Development Assistance.

The country should adopt adequate policies to attract more FDI in the way that it can generate revenues to spend on infrastructures and services which will raise economic growth. Greenfield investment should be encouraged especially in energy production and the manufacturing sector. Transfer of technology or spillover of human skills and technology should be focus from FDI. To get a significant impact of FDI in Niger, adequate bureaucratic and business environment should be created such as sound or healthy public administration, more infrastructures and skills labors.

For remittances to promote economic growth in Niger, it should be directed through channels that promote financial development such as saving, investment. The government should sensitize the diaspora or migrant to direct their remittance towards productive activities that foster growth of the country. Household should be allowed to access financial system or opened bank accounts and then had access to the banking system in order to save fund received from their fellow migrants. The transfer of remittance should be eased by lowering the cost of transfer. 


\section{References}

[1] Riddell, R.C. (2008) Does Foreign Aid Work. Oxford University Press, Oxford.

[2] Sen, A. (1999) Development as Freedom. Oxford University Press, Oxford.

[3] Veiderpass, A and Andersson, P. (2007) Foreign Aid, Economic Growth and Efficiency Development. Swedish Agency for Development Evaluation (SADEV) Reports 1.

[4] Reddy, S.G. and Camelia, M. (2006) Development Aid and Economic Growth: A Positive Long-Run Relation. DESA Working Paper No. 29, JEL-Codes: O1, O2, O4

[5] Easterly, W., Levine, R. and Roodman, D. (2004) Aid, Policies, and Growth: Comment. American Economic Review, 94, 774-780. http://dx.doi.org/10.1257/0002828041464560

[6] Burnside, C. and Dollar, D. (2000) Aid, Policies, and Growth. American Economic Review, 90, 847-868. http://dx.doi.org/10.1257/aer.90.4.847

[7] Alesina, A. and Weder, B. (2002) Do Corrupt Governments Receive Less Foreign Aid? American Economic Review, 92, 1126-1137. http://dx.doi.org/10.1257/00028280260344669

[8] Brautigam, D. and Knack, S. (2004) Foreign Aid, Institutions, and Governance in Sub-Saharan Africa. Economic Development and Cultural Change, 52, 255-285. http://dx.doi.org/10.1086/380592

[9] Moyo, D. (2009) Dead Aid: Why Aid Is Not Working and How There is Another Way for Africa. Farrar, Straus and Giroux, New York.

[10] Bauer, P.T. (1972) Dissent on Development. Harvard University Press, Cambridge.

[11] Driffield, N. and Jones, C. (2013) Impact of FDI, ODA and Migrant Remittances on Economic Growth in Developing Countries: A Systems Approach. European Journal of Development Research, 25, 173-196. http://dx.doi.org/10.1057/ejdr.2013.1

[12] Pia, M.O., Madeline, Z., Jesus, C. and Roberto, C. (2010) Do Remittances Boost Economic Development? Evidence from Mexican States. Federal Reserve Bank of Dallas, Working Paper 1007 (1), 2.

[13] Skeldon, R. (2002) Migration and Poverty. Asia-Pacific Population Journal, 17, 67-82.

[14] Lucas, R.E.B. (2005) International Migration and Economic Development, Stockholm: Expert Group on Development Issues. Swedish Ministry for Foreign Affairs.

[15] Balde, Y. (2009) Migrants’ Remittances and Economic Growth in Sub-Saharan Africa. http://www.umdcipe.org/conferences/Maastricht/conf_papers/Papers/Remittances\%20and\%20Growth\%20in\%20SSA

[16] Roberts, W.B. and Banaian, K. (2004) Remittances in Armenia: Size, Impacts, and Measures to Enhance Their Contribution to Development. (Mimeo)

[17] Leon-Ledesma, M., Piracha, M. and Quillin, B. (2006) Remittances, Institutions and Economic Growth. IZA Discussion Paper, Paper 2139.

[18] Faini, R. (2002) Migration, Remittances, and Growth. http://www.wider.unu.edu/conference/conference-2002-3/conference\%20papers/faini.pdf

[19] Faini, R. (2007) Migration, Remittances and Growth. AFD/EUDN Conference, Paris, France.

[20] Ratha, D. (2003) Workers’ Remittances: An Important and Stable Source of External Development Finance. Global Development Finance, World Bank, Washington DC.

[21] Bettin, G. and Zazzaro, A. (2008) Remittances and Financial Development: Substitutes or Complements in Economic Growth? Hamburg Institute of International Economics, Hamburg.

[22] Miguel, L.-L. and Piracha, M. (2004) International Migration and the Role of Remittances in Eastern Europe. International Migration, 42, 65-84. http://dx.doi.org/10.1111/j.0020-7985.2004.00295.x

[23] Chami, R., Fullenkamp, C. and Jahjah, S. (2005) Are Immigrant Remittance Flows a Source of Capital for Development? IMF Staff Papers, 52, 55-81.

[24] Azam, J. and Gubert, F. (2006) Migrant Remittances and the Household in Africa: A Review of Evidence. Journal of African Economies, 15, 426-462. http://dx.doi.org/10.1093/jae/ej1030

[25] Ajayi, S.I. (2006) FDI and Economic Development in Africa. ADB/AERC International Conference on Accelerating Africas Development Five Years into the Twenty-First Century, Tunis, 22-24 November 2006.

[26] Calvo, M.B. and Sanchez, B. (2002) Foreign Direct Investment, Economic Freedom, and Economic Growth: New Evidence from Latin America. Economics Working Paper No. 4/03, Universidad de Cartabria.

[27] Akinlo, A. (2004) Foreign Direct Investment and Growth in Nigeria: An Empirical Investigation. Journal of Policy Modeling, 26, 627-639. http://dx.doi.org/10.1016/j.jpolmod.2004.04.011 
[28] Ayanwale, A.B. (2007) FDI and Economic Growth: Evidence from Nigeria. African Economic Research Consortium Paper 165, Nairobi.

[29] Hermes, N. and Lensink, R. (2003) Foreign Direct Investment, Financial Development and Economic Growth. Journal of Development Studies, 40, 142-153. http://dx.doi.org/10.1080/00220380412331293707

[30] Aboubacar, B., Xu, D. and Ousseini, A. (2014) Does Trade Openness Matter for Economic Growth in Niger? Theoretical Economics Letters, 4, 916-927. http://dx.doi.org/10.4236/tel.2014.49115

[31] Hendry, D.F. and Juselius, K. (2000) Explaining Cointegration Analysis: Part I. Energy Journal, 21, 1-42. http://dx.doi.org/10.5547/ISSN0195-6574-EJ-Vol21-No1-1

[32] Granger, C.J.W. and Swanson, N.R. (1996) An Introduction to Stochastic Unit Root Processes. Journal of Econometrics, 80, 35-62. 